\section{Prolapse of the third eyelid gland in a mixed breed cat: case report}

\author{
Prolapso da glândula da terceira pálpebra em um gato sem raça \\ definida: relato de caso
}

\author{
Isabela Pessôa Barbieri Bastos* (D), Rayssa Dias Faleiro² (D), Gabriela Pereira Salça de Almeida ${ }^{3}$ (D) Jessica \\ Karoline de Oliveira Chaves 3 (1) \& Diefrey Ribeiro Campos 4 (D) \\ 'Veterinarian, Resident. Programa de Residência em Medicina Veterinária - Oftalmologia Veterinária, Departamento de \\ Medicina e Cirurgia Veterinária (DMCV) Instituto de Veterinária (IV), Universidade Federal Rural do Rio de Janeiro (UFRRJ), \\ Seropédica, RJ, Brasil \\ Veterinarian. Programa de Pós-graduação em Medicina Veterinária (PPGMV), DMCV, IV, UFRRJ, Seropédica, RJ, Brasil \\ Veterinarians. Programa de Pós-graduação em Ciências Veterinárias (PPGCV), Departamento de Parasitologia Animal (DPA), \\ IV, UFRRJ, Seropédica, RJ, Brasil \\ ${ }^{4}$ Veterinarian, DSc. PPGCV, DPA, IV, UFRRJ, Seropédica, RJ, Brasi
}

\begin{abstract}
A 4-year-old male mixed-breed cat was evaluated with a history of the presence of a reddish mass in the left eye medial corner. Ophthalmic examination revealed prolapse of the third eyelid gland, conjunctival secretion and hyperemia. The animal underwent gland replacement surgery using the modified Morgan technique. After surgery, clinical signs improved on the first day. The cat was observed for 2 years after surgery and there was no recurrence of the condition. The surgical technique was effective in resolving the condition.
\end{abstract}

Keywords: ophthalmology, surgery, 'cherry eye', feline medicine.

\section{Resumo}

Um felino de quatro anos de idade, macho e sem raça definida foi atendido com histórico de surgimento de uma massa avermelhada no canto medial do bulbo ocular esquerdo. Ao exame oftalmológico foi observado o prolapso da glândula da terceira pálpebra, hiperemia e secreção em conjuntiva. O animal foi submetido ao procedimento cirúrgico de reposição da glândula pela técnica de Morgan modificada. Após a cirurgia, notou-se melhora dos sinais clínicos. O animal foi acompanhado durante 3 anos após o procedimento e não houve, até o presente momento, a recidiva do prolapso da glândula. Esseé o primeiro caso relatado no Brasil de prolapso da glândula terceira pálpebra em felino. A técnica cirúrgica utilizada foi efetiva na resolução da condição.

Palavras-chave: oftalmologia, cirurgia, 'Olho de cereja', medicina felina.

\section{Introdution}

The third eyedlid is a structure present between the lower eyelid and the cornea, in the medial portion of the lower conjunctival sac. This structure consists of four components: the T-shaped cartilage, the third eyelid gland, lymphoid follicles and the conjunctival tissue that covers the bulbar and eyelid surfaces. The third eyelid gland produces about 30-57\% of the aqueous part of the precorneal tear film and provides protection to the eyeball from the removal of solid debris. The fixation of this gland to the periorbital region is performed by the fascia retinaculum, a structure that acts as a strong ligament (Saito et al., 2001; Hendrix, 2007; Williams et al., 2012).

The prolapse of the gland, also known as "cherry eye", mostly occurs in dogs, and is only rarely observed in cats. The etiology of this condition has not been clearly elucidated, but it is believed that the prolapse of the gland results from a deformity in the retinaculum that connects the gland to the periorbital region, causing looseness of this tissue and allowing eversion of the gland without losing the third eyelid cartilage fixation (Slatter, 2005 ; Merlini et al., 2014).

In dogs, the prolapse of this gland can occur unilaterally or bilaterally. It affects young animals more often and many breeds are predisposed to prolapse the third eyelid gland. In cats, it is
How to cite: Bastos, I. P. B., Faleiro, R. D., Almeida, G. P. S., Chaves, J. K. O., \& Campos, D. R. (2020). Prolapse of the third eyelid gland in a mixed breed cat: case report. Brazilian Journal of Veterinary Medicine, 42, e000820. https://doi org/10.29374/2527-2179.bjvm000820

Financial support: GPSA and JKOC - Received scholarship from CNPq (Conselho Nacional de Desenvolvimento Científico e Tecnológico). DRC - Received scholarship from FAPUR (Fundação de Apoio à Pesquisa Científica e Tecnológica da UFRRJ).

Conflicts of interest: No conflict of interests declared concerning the publication of this article.

Received: October 29, 2020.

Accepted: November 3, 2020.

The study was carried out at Laboratório de Quimioterapia Experimental em Parasitologia Veterinária, Departamento de Parasitologia Animal, Instituto de Veterinária, Universidade Federal Rural do Rio de Janeiro - UFRRJ, Campus Seropédica, Seropédica, RJ, Brasil.

\section{*Correspondence}

Isabela Pessôa Barbieri Bastos Departamento de Medicina e Cirurgia Veterinária, Instituto de Veterinária, Universidade Federal Rural do Rio de Janeiro - UFRRJ, Rodovia BR 465, Km 7, Campus Universitário, Bairro Zona Rural CEP 23897-000 - Seropédica (RJ), Brasil E-mail: isabelapbbastos@gmail.com

Copyright Bastos et al. This is an Open Access article distributed under the terms of the Creative Commons Attribution Non-Commercial License, which permits unrestricted non-commercial use, distribution and reproduction in any medium provided the original work is properly cited. 
believed there is predisposition of the Burmese cats (Koch, 1979; Christmas, 1992). However, a few reports indicate its occurrence in domestic shorthair and Persian (Albert et al., 1982; Schoofs, 1999; Chahory et al., 2004; Williams et al., 2012). The clinical signs most commonly associated with prolapse of the third eyelid gland include ocular secretion and conjunctival inflammation (Chahory et al., 2004; Wouk et al., 2009; Williams et al., 2012).

The recommended treatment is surgical repositioning of the gland. The gland's complete excision from the third eyelid gland is a predisposing factor for the development of dry keratoconjunctivitis (Almeida et al., 2004; Merlini et al., 2014). Several surgical techniques are described for repositioning, and can be divided into two main types: anchoring techniques and pocket techniques (Blogg, 1979; Albert et al., 1982; Kaswan \& Martin, 1985; Stanley \& Kaswan, 1994; Chahory et al., 2004).

Due to the rarity of the prolapse the third eyelid gland, the different surgical techniques and their results are poorly described for these animals. This article describes a case of prolapse the third eyelid gland in a domestic shorthair cat with surgical resolution using Morgan's conjunctival pocket technique.

\section{Case description}

A castrated 4-year-old male mixed-breed cat, not infected by feline retroviruses, was presented with spontaneous prolapse of a reddish mass in the medial corner of the eye. Besides the prolapse, conjunctival secretion and hyperemia were observed (Figure1). The ophthalmological examination showed intense conjunctival hyperemia, seromucous secretion, protruded the gland of the third eyelid and swollen left eye. The Schirmer lacrimal test presented normal value $20 \mathrm{~mm} / \mathrm{min}$ in both eyes. The threat response was present in both eyes, as well as direct pupil and consensual positive light reflex. The intraocular pressure, measured with a rebound tonometer (Tonovet-Icare ${ }^{\circ}$ ), presented normal values, $19 \mathrm{mmHg}$ in the right eye and $18 \mathrm{mmHg}$ in the left eye. A biomicroscope was used to evaluate sclera, cornea, anterior chamber, iris, posterior chamber and lens, and no alterations were observed. The fluorescein test was negative in both eyes, revealing corneal integrity. Fundoscopy performed with a PanOptic ${ }^{\mathrm{TM}}$ ophthalmoscope found results within normal range.

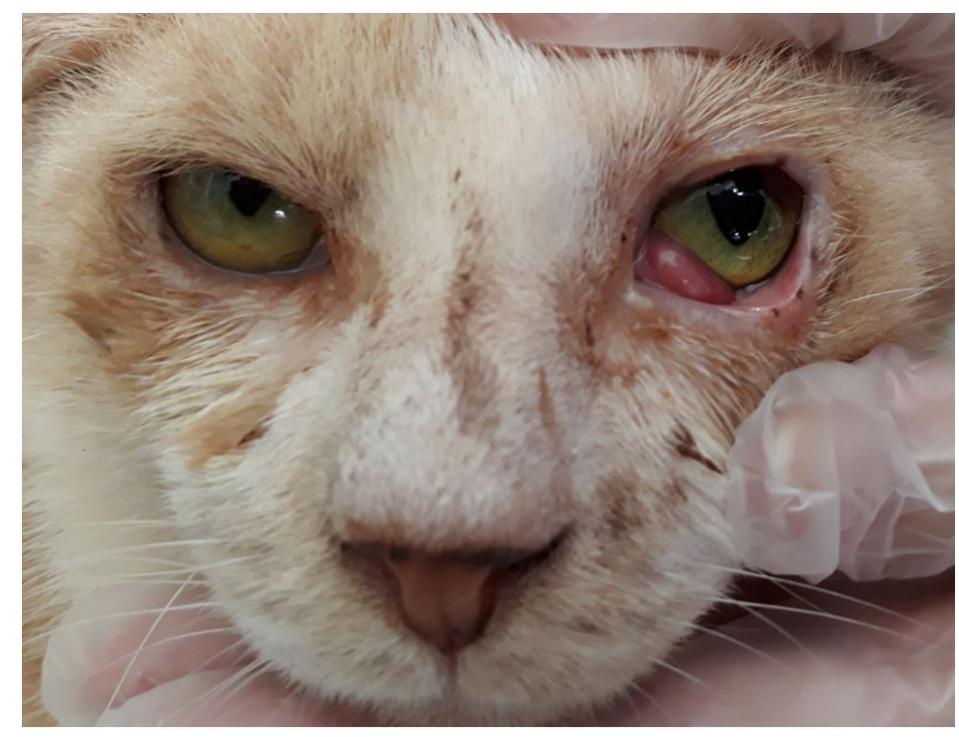

Figure 1. Prolapse of the third eyelid gland in four years old, male, mixed breed cat. It is possible to observe a reddish mass in the left eye medial corner.

Cardiovascular risk, blood biochemistry and hematological exams were performed before the surgery. No abnormalities that compromised anesthesia or surgery were detected. For the surgery, the Morgan technique was chosen to reposition the gland. The anesthetic protocol included $0.3 \mathrm{mg} / \mathrm{kg}$ of midazolam and $0.5 \mathrm{mg} / \mathrm{kg}$ of methadone, given intramuscularly as preanesthetic 
medication. Induction was performed with intravenous propofol at a dose of $6 \mathrm{mg} / \mathrm{kg}$, and maintenance was by inhalation anesthesia with isoflurane.

The Morgan technique was performed as described by Morgan et al. (1993). Initially, the bulbar surface of the third eyelid was exposed using two Halsted calipers. Then two parallel incisions were made in the bulbar conjunctiva, one lateral and the other medial to the protuberant gland, both approximately $1 \mathrm{~cm}$ in length. The stiches started at the eyelid surface of the nictitating membrane and then were guided by a wire through the needle, emerging at the bulbar surface. A Cushing suture was performed using 5-O nylon thread. At the end of the suture, along with the pull on the wire, slight pressure was placed on the gland to reduce it to a conjunctival pocket. The needle was directed to the eyelid surface of the nictitating membrane to finalize the suture node, ending the surgical technique.

The postoperative protocol consisted tobramycin ( $3 \mathrm{mg} / \mathrm{mL})$ and dexamethasone $(1 \mathrm{mg} / \mathrm{mL})$ (TobraDex ophthalmic suspension; Alcon), with one drop being administered every six hours for seven days. For analgesia, dipyrone drops (Neo Quimica ${ }^{\circledR}$ ) were administered orally at a dose of $25 \mathrm{mg} / \mathrm{kg}$ every 12 hours and meloxicam (Maxicam ${ }^{\circledR}$; Ourofino) at an oral dose of 0.05mg/kg every 24 hours for five days.

A new ophthalmological examination was performed 15 days after the surgery. No secretion or hyperemia was observed, and the gland was in correct anatomical position (Figure 2). The Schirmer tear test presented normal values $18 \mathrm{~mm} / \mathrm{min}$ in the right eye and $15 \mathrm{~mm} / \mathrm{min}$ in the left eye. The animal was observed for two years after repositioning, and there was no recurrence of the condition. The presence of hyperemia and secretion in the left eye was also no longer observed.

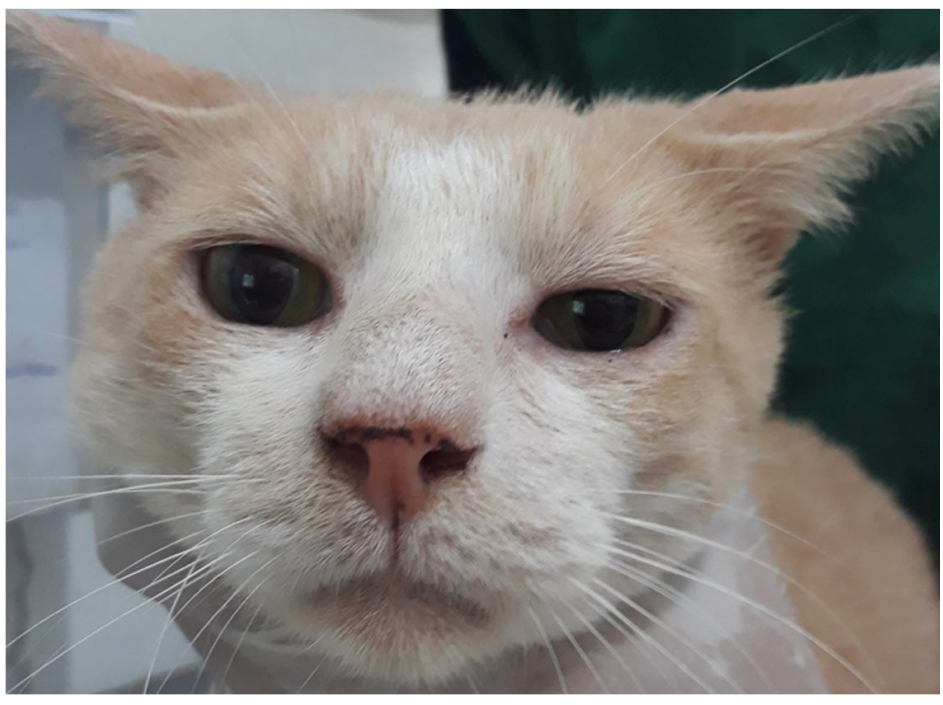

Figure 2. Patient 15 days after surgical correction prolapsed third eyelid gland. It is possible to observe that the gland of the left eye is in its correct anatomical position.

\section{Discussion}

Prolapse of the third eyelid gland is an uncommon condition in domestic cats (Merlini et al., 2014). In the case presented, the cat diagnosed with a spontaneous prolapse of the third eyelid gland was a four-year-old mixed-breed. Unlike in dogs, where prolapse of this gland occurs mainly in young animals, in cats it is more often observed in middle-aged animals (Schoofs, 1999; Chahory et al., 2004).

As far as breed predisposition is concerned, published works show a higher occurrence in the Burmese breed (Koch, 1979; Albert et al., 1982; Christmas, 1992). However, cases have been described in other short-haired and Persian cats (Schoofs, 1999; Chahory et al., 2004; Williams et al., 2012).

It is believed that late occurrences are not related to a genetic predisposition, instead being associated with some ocular disturbance, such as conjunctivitis or trauma. The occurrence of 
prolapse is followed by the development of an inflammatory process that leads to the appearance of clinical signs of conjunctivitis and ocular secretion (Gelatt, 2003; Slatter, 2005; Wouk et al., 2009).

The values of the Schirmer test before and after surgery were within the normal values for the species (reference: 15-25mmHg), but after surgery the value was lower. The discomfort generated by the inflammatory reaction due to the prolapse of the gland may lead to stimulation of lacrimal production, thus increasing the values before surgery. The pressure values measured before and after repositioning of the gland were within normal parameters, suggesting that this condition does not interfere with intraocular pressure.

In order to correct the prolapse of the third eyelid gland in this case, Morgan's conjunctival pocket technique was performed due to its good functionality and low recurrence rates when used in dogs. (Delgado, 2005). With the chosen technique, the first and last suture node was in the eyelid surface of the third eyelid, preventing the contact of the wire with the cornea. This technique avoids the appearance of complicated corneal and postoperative ulcers, which were not observed in this reported case. The result of this technique was good in this case. Two years after the surgical procedure, the cat did not present recurrence and did not show clinical signs indicating ocular disease conditions.

\section{Conclusion}

This report demonstrates that the prolapse of the third eyelid gland occurred spontaneously in the cat and was an isolated ocular disorder. The repositioning of the gland by Morgan's pocket technique was successful to correct this condition.

\section{Acknowledgements}

For their support of in part by the Conselho Nacional de Desenvolvimento Científico e Tecnológico (CNPq), Fundação de Apoio à Pesquisa Científica e Tecnológica da UFRRJ (FAPUR) and the Ministério da Educação (MEC).

\section{References}

Albert, R. A., Garrett, P. D., Whitley, R. D., \& Thomas, K. L. (1982). Surgical correction of everted third eyelid in two cats. Journal of the American Veterinary Medical Association, 180(7), 763-766. PMid:7085457.

Almeida, D. E., Mamede, F. V., Duque Ortiz, J. P., \& Laus, J. L. (2004). Iatrogenic keratoconjunctivitis sicca in a dog. Ciência Rural, 34(3), 921-924. http://dx.doi.org/10.1590/S0103-84782004000300041.

Blogg, J. R. (1979). Surgical Replacement of a Prolapsed Gland of Third Eyelid ('Cherry eye') a New Technique. Australian Veterinary Practitioner, 9, 75.

Chahory, S., Crasta, M., Trio, S., \& Clerc, B. (2004). Tree cases of prolapse of the nictitans gland in cats. Veterinary Ophthalmology, 7(6), 417-419. http://dx.doi.org/10.1111/j.1463-5224.2004.04039.x. PMid:15511284.

Christmas, R. (1992). Surgical correction of congenital ocular and nasal dermoids and third eyelid gland prolapse in related Burmese kittens. The Canadian Veterinary Journal. La Revue Veterinaire Canadienne, 33(4), 265266. PMid:17423987.

Delgado, E. (2005). Recolocação cirúrgica da glândula da membrana nictitante em canídeos pela técnica de bolsa conjuntival - 23 casos clínicos. Revista Portuguesa de Ciências Veterinárias, 100, 89-94.

Gelatt, K. N. (2003). Doenças e cirurgia de terceira palpebra do cão. In K. N. Gelatt. Manual de oftalmologia veterinária (pp. 76-87). São Paulo: Manole.

Hendrix, D. V.H. (2007) Canine conjunctiva and nictitating membrane. In K. N. Gellat. Veterinaryophthalmology (pp. 662-689). Hoboken: Blackwell Publishing.

Kaswan, R. L., \& Martin, C. L. (1985). Surgical correction of third eyelid prolapse in dogs. Journal of the American Veterinary Medical Association, 186(1), 83. PMid:3965435.

Koch, S. A. (1979). Congenital ophthalmic abnormalities in the Burmese cat. Journal of the American Veterinary Medical Association, 174(1), 90-91. PMid:457577.

Merlini, N. B., Guberman, U. C., Gandolfi, M. G., Souza, V. L., Rodas, N. R., Ranzani, J. J. T., \& Brandão, C. V. C. (2014). Estudo retrospectivo de 71 casos de protrusão da glândula da terceira pálpebra (2009-2013). Arquivo de Ciências Veterinárias e Zootecnia da UNIPAR, 17, 177-180. http://dx.doi.org/10.25110/arqvet.v17i3.4941.

Morgan, R. V., Duddy, J. M., \& McClurg, K. (1993). Prolapse of the gland of the third eyelid in dogs: a retrospective study of 89 cases (1980 to 1990). Journal of the American Animal Hospital Association, 29, 56-60.

Saito, A., Izumisawa, I., Yamashita, K., \& Kotani, T. (2001). The effect of third eyelid gland removal on the ocular surface of dogs. Veterinary Ophthalmology, 4(1), 13-18. http://dx.doi.org/10.1046/j.1463-5224.2001.00122.x. PMid:11397314. 
Schoofs, S. H. (1999). Prolapse of the gland of the third eyelid in a cat: a case report and literature review. Journal of the American Animal Hospital Association, 35(3), 240-242. http://dx.doi.org/10.5326/15473317-35-3-240. PMid:10333264.

Slatter, D. (2005). Terceira pálpebra. In D. Slatter. Fundamentos de oftalmologia veterinária (3. ed, pp. 247-257). São Paulo: Rocca.

Stanley, R. G., \& Kaswan, R. L. (1994). Modification of the orbital rim anchorage method for surgical replacement of the gland of the third eyelid in dogs. Journal of the American Veterinary Medical Association, 205(10), 14121414. PMid:7698920.

Williams, D., Middleton, S., \& Caldwell, A. (2012). Everted third eyelid cartilage in a cat: a case report and literature review. Veterinary Ophthalmology,15(2), 123-127. http://dx.doi.org/10.1111/j.1463-5224.2011.00945.x. PMid:22051051.

Wouk, A. F. P. F., Souza, A. L. G., \& Farias, M. R. (2009). Afecções dos anexos oftálmicos. In J. L. Laus. Oftalmologia clínica e cirúrgica em cães e gatos (pp. 33-68). São Paulo: Roca 